\title{
Investigating the Impact of Long-term Professional Development through Teacher Evaluation*
}

\begin{tabular}{ccc}
\hline Article Type & Received Date & Accepted Date \\
Research & 19.03 .2020 & 17.07 .2020 \\
\hline
\end{tabular}

\section{Özlem Oktay ${ }^{* *}$}

\author{
Ali Eryılmaz ${ }^{* * *}$
}

\begin{abstract}
Educational reform efforts support professional development (PD) programs for teachers as a means to establishing possible outcomes that may affect changing teacher practices, student learning, and impact on economic and educational foundations. PD programs require evaluation in order to appraise their effectiveness, and seeking participant opinion following program implementation is one such valid method. The aim of the current study is to determine in-service physics teachers' evaluation about the impact of a long-term PD program. Qualitative research methodology was employed in this study. Research was conducted with seven teachers, with data collected through a workshop session evaluation checklist (WSEC) and a PD program evaluation interview protocol (PDEIP). Interviews were audio-recorded and then responses to each question transcribed. According to the WSEC data, all sessions broadly reached their aims. The session which teachers considered the least contributive to their developmental gain was on the topic of "Misconception." The PDEIP results showed that teachers used more student-centered methods and more varied teaching materials in their lessons following their participation in the PD program. Following the PD program, some teachers reportedly started using placement assessment.
\end{abstract}

Keywords: Professional development, in-service physics teachers, teacher evaluation, qualitative study.

\footnotetext{
* This research article is a part of the first author's $\mathrm{PhD}$ dissertation.

** Corresponding Author: Dr., Atatürk University, Kazım Karabekir Education Faculty, Department of Mathematics and Science Education, Erzurum, Turkey. E-mail: oktayozlm@ gmail.com, https://orcid.org/0000-0002-0207-1211

*** Prof. Dr., Middle East Technical University, Faculty of Education, Department of Mathematics and Science Education, Ankara, Turkey. E-mail: eryilmaz@metu.edu.tr, https://orcid.org/0000-0003-2161-6018
} 


\section{Uzun Süreli Mesleki Gelişimin Etkisinin Öğretmen Değerlendirmesi ile Araştırılması ${ }^{*}$}

\begin{tabular}{ccc}
\hline Makale Türü & Başvuru Tarihi & Kabul Tarihi \\
Araştırma & 19.03 .2020 & 17.07 .2020 \\
\hline
\end{tabular}

\begin{abstract}
Özlem Oktay **
Ali Eryılmaz ${ }^{* * *}$

$\ddot{\mathbf{O z}}$

Eğitim reform çabaları değişen öğretmen uygulamalarını, öğrencinin öğrenmesini, ekonomik ve eğitimsel temelleri etkileyebilecek olası sonuçlar elde etmenin bir yolu olarak öğretmenlerin mesleki gelişim (MG) programlarını desteklemektedir. MG programları, etkilerinin ortaya çıkması için değerlendirme yapılmasını gerektirir ve programın uygulanmasından sonra katılımcı fikrinin alınması bunun için geçerli yöntemlerden biridir. Bu çalışmanın amacı, fizik öğretmenlerinin uzun süreli bir MG programının etkisine ilişkin değerlendirmelerini belirlemektir. Bu çalışma nitel bir araştırmadır. Araştırma yedi öğretmen ile yürütülmüş, veriler Çalıştay Oturum Değerlendirme Listesi (ÇODL) ve Mesleki Gelişim Eğitiminin Değerlendirilmesi ile ilgili Öğretmen Görüşme Formu (MGÖGF) ile toplanmıştır. Görüşmeler sesli olarak kaydedilmiş ve sonra her soruya ait cevaplar transkript edilmiştir. ÇODL verilerine göre, tüm oturumlar amaçlarına geniş ölçüde ulaşmıştır. Öğretmenlerin gelişimsel kazanımlarına en az katkıda bulunduğu düşünülen "Kavram yanılgıları" konusu ile ilgili oturumdur. MGÖGF sonuçları genel anlamda özetlenirse, MG programından sonra öğretmenler derslerinde daha çok öğrenci merkezli yöntemler ve daha çeşitli öğretim materyalleri kullandıklarını belirtmişlerdir. Ek olarak, bazı öğretmenler yerleştirme (placement) amaçlı değerlendirmeyi derslerinde kullanmaya başladıklarını ifade etmiş̧lerdir.
\end{abstract}

Anahtar Sözcükler: Mesleki gelişim, fizik öğretmenleri, öğretmen değerlendirmesi, nitel çalışma.

\footnotetext{
* Bu araştırma makalesi, ilk yazarın doktora tezinin bir parçasıdır.

** Sorumlu Yazar: Dr., Atatürk Üniversitesi, Kazım Karabekir Eğitim Fakültesi, Matematik ve Fen Bilimleri Eğitimi Bölümü, Erzurum, Türkiye. E-posta: oktayozlm@gmail.com, https://orcid.org/0000-0002-0207-1211

*** Prof. Dr., Orta Doğu Teknik Üniversitesi, Eğitim Fakültesi, Matematik ve Fen Bilimleri Eğitimi Bölümü, Ankara, Türkiye. E-posta: eryilmaz@metu.edu.tr, https://orcid.org/0000-0003-2161-6018
} 


\section{Introduction}

Educational reform initiatives cannot succeed without teachers' involvement. Reform efforts support professional development (PD) programs as a means to establishing possible outcomes that may affect changing teacher practices, student learning, and impact on economic and educational foundations. PD of teachers is one of the biggest investments in education. According to the definition put forward by Guskey (1986), PD is an organized initiative for change. Change can be in teachers' classroom implementations, their attitudes, beliefs, or in student learning. PD includes various activities in specific disciplines that contribute to teachers' learning. PD introduces deep learning of content and offers appropriate tools associated with curriculum and learners' needs. Effective teaching requires using proper instructional practices, content understanding, and the effective integration of content and pedagogy in teaching (Ball, 2000).

Of the PD models established in the literature, one of the more well-known is by Bell and Gilbert (1996). Their model includes personal, social, and professional development attributes. The PD model contains three phases, and each phase includes all three types of development. The personal development phase requires solving problems associated with the practice of teaching. The social development phase includes collaboration with peers, during which teachers start to build professional relationships with their colleagues. Then they search for different development opportunities that are relevant to their PD. In the professional development phase, PD emerges from developing more consistent practice. Teachers prepare and implement new activities in the classroom.

Guskey and Sparks (1996) proposed a model with three factors that affect the quality of PD programs. Content is the first factor, and represents the "What" variable. It relates to the new knowledge, skills acquired, subject matter and understanding of pedagogical knowledge during PD, and the involvement of parents in the support of student learning. Second is the process factor, which is the "How" variable when organizing and implementing PD. The third factor is context, in which the "Who," "When," "Where," and "Why" variables are addressed, such as institute, society, and system.

Kubitskey, Fishman, and Marx (2002) examined a design approach model, suggesting four elements of a PD framework as planning, activities, community, and structure. Planning should start with descriptions of PD and support continuous PD assessment. Activities provide the active learning of subjects. Community leads to collaborative working among participants from the same grade, discipline, or institution. Structure is related to the classroom needs of teachers and their experiences.

The problem-based learning PD model explained by Clossen (2008) utilizes small groups to solve problems. A trainer or group leader presents the problem, and then supports the groups. Learning together is utilized in order to identify problems and reach a consensus on a way forward. Teachers spend their time within a socially supportive environment in applying new knowledge and sharing their ideas.

Oktay (2015) proposed a professional development model for in-service physics teachers in order to provide support and feedback so as to build upon their teaching models within the context of physics teaching. The proposed PD program also aimed at overcoming common misunderstandings related to subject content. The PD model framework includes teachers working together face-to-face on a voluntary basis through workshops and other non-face-to-face interactive forms. Considering adult learning theory, this model incorporates effective PD characteristics in a research designed to investigate what happens before and after the implementation of a PD program in terms of teacher practices. A set of 12 PD characteristics were formulated in the PD model framework, and these are: Considering the needs of participants; Raising participants' awareness related to current situation; Providing support; Considering motivating elements towards training participation; Applying feedback strategies; Providing opportunities to practice; Developing planned but flexible PD programs that include effective communication; Considering long-term duration and ongoing structure; Developing a content-specific PD program aligned with curricula; Providing an active learning environment (effective/productive working, reflective thinking, and discussion); Including interactive and collaborative working; and, Building a learning community. An illustration of Oktay's (2015) PD model framework can be seen in Figure 1. 


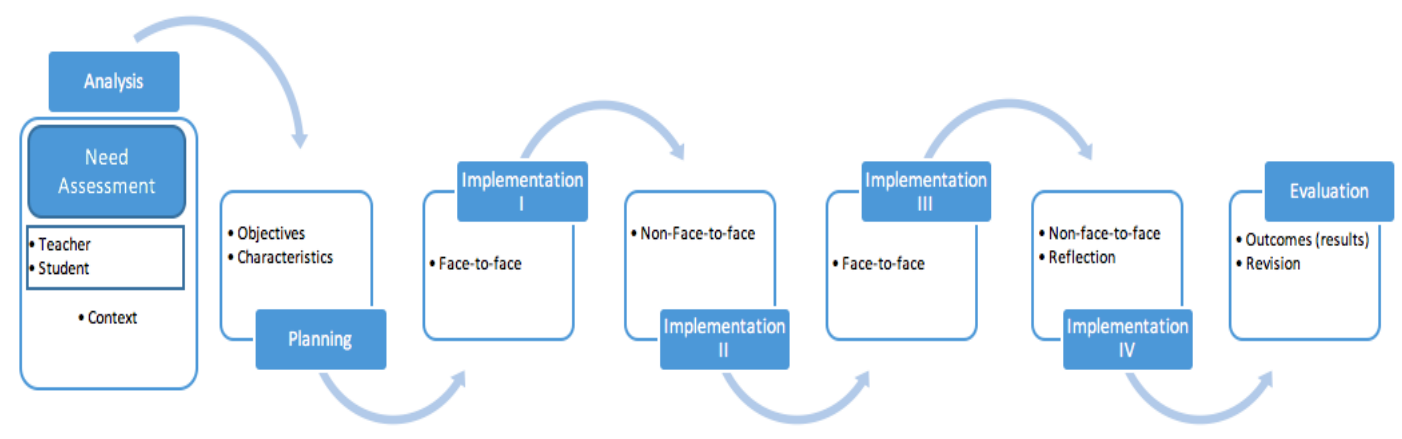

Figure 1. PD model framework (Oktay, 2015)

In Oktay's (2015) study, data were collected from a proposed PD model aimed at improving inservice physics teachers' practices. Since the Turkish physics curriculum was updated in 2013, inservice physics teachers' classroom practices were assessed on the common topics of two units: "Nature of Physics" (NOP) in 2012 and "Introduction to Science of Physics" (ISOP) in 2013. Classroom documents were used to provide evidence for teachers' behavioral changes in their classrooms. Teachers also evaluated themselves with regards to their own changes following attendance of the PD program. In addition, the teachers opined about the strengths and weaknesses of the PD program.

The purpose of the current study is to evaluate Oktay's (2015) proposed model framework through teachers' opinions. Guskey (2000) emphasized five levels of PD evaluation in order to measure its impact, which are: Participants' reactions; Participant learning; Organizational support and change; Participants' usage of new knowledge and skills; and, Student learning. Evaluation is also necessary to determine if any future program should be accepted, revised, or rejected (Ornstein \& Hunkins, 1988). From the results of the current study, it is aimed to see the changes from a participants' perspective, and as such, the following research question forms the root of the study's investigation: "What are the evaluations of in-service physics teachers after participating in a long-term professional development program?

\section{Method}

\section{Participants}

The study was conducted with seven teachers (one male, six female). For the purposes of maintaining participant anonymity, the teachers are referred to in this study as TA, TB, TC, TD, TE, $\mathrm{TF}$, and TG. The participant teachers had an average of 20.7 years teaching experience.

\section{Instruments}

Teachers' evaluations were assessed using a workshop session evaluation checklist (WSEC) and a PD program evaluation interview protocol (PDEIP). At the end of each day's session of Workshop I, a WSEC was given to each participant in-service teacher. The WSEC includes six Likert-type statements and one general question in order to elicit positive and negative feedback from that day's session. The teachers' reactions were measured by way of a set of questions at the end of the teacher PD program using the PDEIP. It was constructed consisting of five open-ended questions and a rating scale. The participant teachers were then requested to provide their opinion about the PD activities overall and to evaluate the strengths and weaknesses of the PD program. Data were collected from the participant teachers through 40 minute semi-structured interviews that were audio-recorded with the permission of the participants.

\section{Research Methodology and Data Analysis}

The study utilizes qualitative methodology. Interviews were audio-recorded and then transcribed question by question. The researcher wrote notes and codes on the manuscripts. The researchers then reread the data many times over in order to be familiar with the contexts. A thematic approach (Miles 
\& Huberman, 1994) was used to analyze the coded transcripts. During the interviews, everyday vocabulary was preferred instead of using terminology. Prompts (nonverbal noises such as "Ok" and "Yes") and probes (e.g., Had anyone else mentioned similar thoughts?) were used to stimulate and expand discussions.

The validity and reliability of the qualitative findings were ensured through the following. First, the two researchers consulted with each other while developing the tools, and when collecting, coding, analyzing, and interpreting the data. Iterations of the data analysis were debated until final consensus as reached. Experts also gave feedback during the development of the measurement tools. In reporting the results, narratives from the data are given as quotations so as to reflect the actual teachers' responses. To ensure dependability of the analysis, interrater (agreement among different researchers) reliability was calculated, with scores found as being $94 \%$ and $95 \%$, respectively. As these scores far exceed the $70 \%$ acceptability mark, the results are considered to be reliable (Miles \& Huberman, 1994).

Participants were made fully aware of the purpose of the study and the measuring tools employed; therefore, there was no element of deception on behalf of the participants of the study. Permissions were taken from the teachers prior to audio-recording their interviews. In reporting the results of the study, the teachers' names were coded as letters of the alphabet for the sake of maintaining participant anonymity. No data was shared with any third parties. The teachers had the opportunity to withdraw their participation from the study at any time.

\section{Procedure}

Workshop I included a total of 20 hours in five sessions of four hours, and included both theoretical and practical applications. Data from WSEC were obtained from Workshop I.

The first activity in Session 1 was about the SI unit system and basic quantities; whereas, the second activity related to the scalar and vector quantities. Lastly, the semester's observation results were overviewed in Session 2 in terms of teaching strategies. Good examples related to teaching methods were displayed by some of the teachers (e.g., modeling activity, argumentation: technology and physics, a scientific method from Galileo, measurement of mass and length). Session 3 started with a Science and Society activity that is generally used as an introduction to the Nature of Science (NOS) concept (Cavallo, 2008). How a scientist works and uses scientific processes were tested by the teachers in their activity. Misconceptions and cautions were the main topic of Session 4. An academician who is an expert in the field of NOS attended the session in order to provide knowledge and material support. $\mathrm{He}$ lectured on superconductivity and demonstrated the Meissner Effect, and integrated scientific law and theory concepts into the activity. The last session was devoted to the assessment dimension, and an academician was invited along to the training. The expert wanted to draw attention to assessment techniques that could be employed for different purposes, and focused on placement, formative, diagnostic, and summative assessments.

At the end of the all the sessions, the teachers evaluated them using the WSEC. Semi-structured interviews were then conducted with the teachers based on what the teachers took from the PD program using PDEIP. The participating teachers of the study were divided into lower and upper groups, according to a participation rate of approximately $80 \%$ (participation value having sharp changes) and then results were discussed.

\section{Results}

\section{Evaluation of the Professional Development Workshop}

The participant teachers performed an evaluation at the end of each session, using six statements in a five-point, Likert-type format. Figure 2 illustrates the evaluations that the teachers made following the training received in each session of Workshop I. 


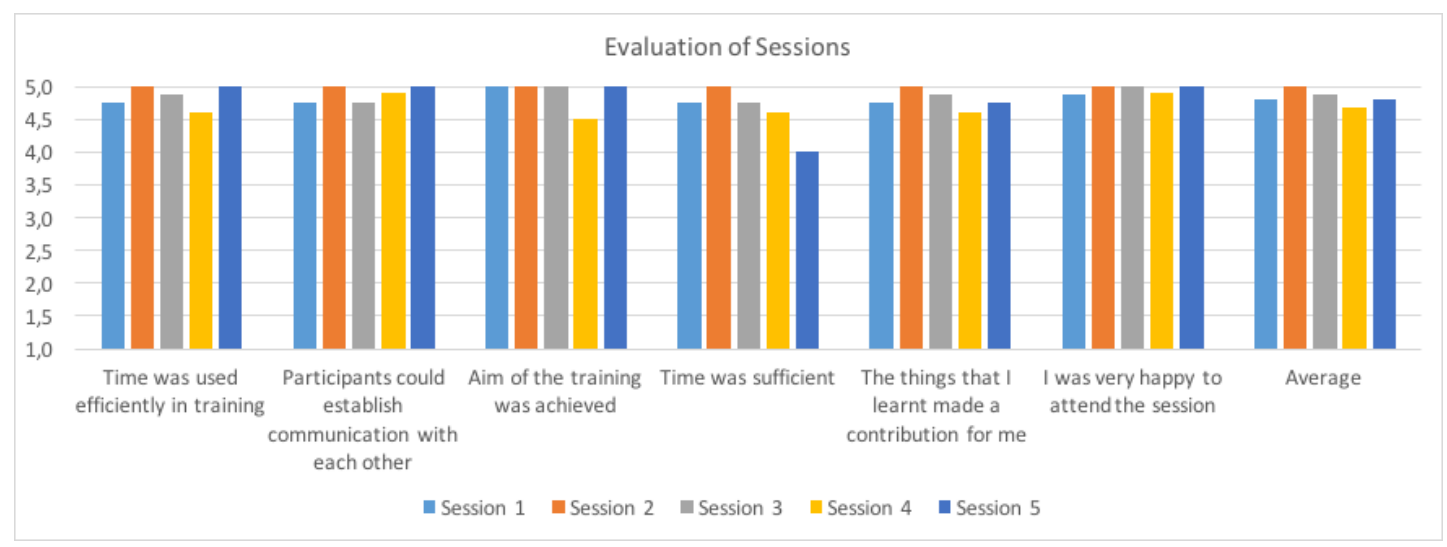

Figure 2. Evaluation of sessions

It was observed that the teachers were generally satisfied with the sessions (Item 6). The teachers stated that training in Session 4, in which misconception content was covered, achieved its goal less than in the other sessions (Item 3, average 4.5). According to the teachers, the purpose was achieved completely in all other sessions. The level of participants being able to establish communication with each other was evaluated in the range of 4.8 to 5.0 (Item 2). As observed, the level of being able to establish minimum communication was $95 \%$. The lowest value given for efficient time usage in the training was 4.6 on average (Item 1 and Item 4) in Session 4. Session 2 and Session 5 were reported as the sessions in which time was used most efficiently, and Session 5 was the shortest session, followed by Session 4 in which misconception was the content. In Session 2 on methods, the teaching strategies were considered entirely sufficient in terms of time usage. Lastly, Session 4 was reported as the session in which teachers thought that what had been learnt had made the least contribution for the participants (Item 5, average: 4.6). When the sessions were generally evaluated according to their average point, they are arranged respectively as Session 2, Session 3, Session 1, Session 5, and Session 4.

\section{Evaluation of Strengths and Weaknesses of the PD Program}

In this section, questions measuring the impact of the PD program in the delivery of the unit, and whether or not the training was efficient and effective were asked using the PDEIP. Teachers were posed these questions after participating in the PD program and after they had an opportunity to implement what they had learned into their teaching.

\section{In this semester, did you deliver the ISOP unit by student-centered or teacher-centered method? Please explain.}

Four from a total of seven teachers who participated in the study mentioned that they delivered the ISOP unit by involving the participation of their students more in the lesson. The teachers stated that they used student-centered lesson delivery method as follows (see Table 1).

\section{Table 1}

Number of teachers and student-centered lesson delivery methods

\begin{tabular}{lc}
\hline \multicolumn{1}{c}{ Student-centered lesson delivery method } & Number of teachers \\
\hline $\begin{array}{l}\text { Student participation in the learning process, lesson } \\
\text { (question-answer, asking for ideas) }\end{array}$ & 5 \\
Using visual materials & 3 \\
Student projects and experiments & 2 \\
Motivating students, drawing their attention to the lesson & 2 \\
Assigning research topics before and after the lesson & \\
(or assignment) & \\
\hline
\end{tabular}


The teachers applied a student-centered lesson delivery method by asking students for their ideas, and then involving them more actively in the process. The materials used, and the projects and experiments performed all contributed to this process, together with the given assignments. The teacher stated her view on this subject as follows:

I tried to use a more student-centered method after the PD program. I tried to get the students to join in the process and the lesson by taking on their ideas. I tried to use different teaching strategies and activities in the lesson after the PD program. In addition, sometimes I just lectured according to the situation. If we left it up to the children, then time and the management of class could be lost, and two whole physics lessons spent on making an activity. In summary, it has been different from last year, but I am satisfied (Teacher TD).

One teacher emphasized both the students' behaviors and skills from the past, and the impact of class level on the application of new things learned from the PD.

The purpose was to engage students in the activities more by putting them at the center of the process, but when we consider their skills and behaviors from past years, then teacher-centered method was automatically more prominent. Unfortunately, the class did not perform as I had hoped and requested; the other classes were better in this lesson (Teacher TE).

2. Please explain the positive and negative changes occurred in your inter-class applications after taking the PD program considering the following issues;

a) In terms of content of the unit (common topics and skill objectives), did your students experience any difficulties in this dimension? Please explain.

The teachers stated that "They care more about the objectives" after the PD program (four teachers). For example, one stated that:

We knew the subjects, but we didn't pay too much attention to the objectives. I tried to determine which objectives to focus upon, and which objectives to give at which level. I thought whether I should prepare exam questions according to the objectives and whether I could measure the students. Additionally, I became aware of looking more at the curriculum. I paid more attention as to which questions the students were unable to answer in the exam. I adopted objective-focused lesson delivery more, although they still experienced problems on certain units and they couldn't understand the modeling (Teacher TG).

Besides, historical development, dependent-independent variables, evidence-inference as new subjects have begun to be given in lessons. The hardest subjects for the students at this level are:

- Using units

- Making a hypothesis

- Law, theory-related misconceptions

- Making mathematical modeling

Another teacher, who has a successful student profile, stated the following:

I had to face the students myself, because the books available on the market are not written in accordance with the objectives. For example, I didn't deliver unit transformation to the students as it is not part of the new curriculum, but students told me that they saw it in many books and they questioned why they didn't learn it (Teacher TC).

b) In terms of teaching strategy (tasks/activities), did your students experience any difficulties in this dimension? Please explain.

All of the teachers said that they delivered "Richer" lessons in terms of teaching strategies after the PD program. They provided the environment by implementing group works (three teachers), and doing different experiments (two teachers). Two of the teachers stated that they used the simple pendulum activity in Workshop I. But, the most encountered problem especially in group works and activities was the noise. The teachers considered that the situation was due to students not being used to this kind of work, and their past experiences not being very positive in this way.

This year, I tried an activity with my students with a simple pendulum and they liked it. We solved the puzzle we developed in the PD program together and I saw variety in the methods they used compared to last year (Teacher TD). 
c) In terms of technology/material you use, did your students experience any difficulties in this dimension? Please explain.

Most of the teachers mentioned that they started using more materials in their lessons after the PD program (five teachers). They began to use the smartboard more and delivered lessons with visual materials such as video and simulations. As a result, the students paid more attention to the lessons which also appeared to be more enjoyable (two teachers). Besides, the students prepared materials such as posters (two teachers), a history line (one teacher), and a board (two teachers). On this topic, one teacher said:

I made them watch videos, which I hadn't done before. They used the technology, they prepared posters and made up boards. For example, they prepared a history line about the historical development of an atom. I wanted to make them prepare different materials and use other things. I think that the students liked it and I will now use it as a performance assignment. I collected the materials prepared by students in order to use as examples next year (Teacher TB).

d) In terms of assessment approach used (measuring prior knowledge, revealing difficult subjects, measuring what is known/not known in the process, and awarding grades), did your students experience any difficulties in this dimension? Please explain.

Six of the teachers mentioned that they started to prepare questions more carefully after the PD program. For example, they started to consider the objectives more in their question preparation, and they understood that they should ask questions in terms of skills measurement. Following the PD program, three of the teachers started creating exams for placement purpose for the first time. Some of the teachers prepared exams measuring the pre-knowledge of students, whilst some of them prepared rubrics for the purpose of performance assessment (three teachers). However, two of the teachers mentioned that such activities take time and that they were not used to such kinds of activities. One of the teachers summarized her lesson assessment process as the following:

I used assessment for placement. I made the students solve example questions we used in the PD program in the lesson. In the process, I prepared worksheet papers and gave them to the students; this showed its benefit with the high grades that they achieved in their first physics exam (Teacher TB).

3. Was there anything you couldn't do this year but plan to do next semester in the four dimensions of the PD program (content/skills/misconceptions, teaching strategies, technologies/materials and assessment approaches)? If any, please briefly explain the reason why they couldn't be achieved this semester.

Table 2 summarizes the activities planned for the next semester's lessons, and weren't made in the first applications following the PD program, and the reasons why.

\section{Table 2}

Future planned activities, and reasons for not implementing this semester

\begin{tabular}{ll}
\hline Future planned activity & Reason not yet implemented \\
\hline Misconceptions tests & Lack of time \\
Worksheets & Lack of time \\
Preparation of visuals & Lack of time \\
Assigning project with strict follow-up & Lack of time \\
Increased number of experiments & Lack of experience \\
Asking for students' written opinions & Lack of time \\
Application of things learned to other units & Lack of experience \\
Presentations by students & Lack of time \\
\hline
\end{tabular}

One teacher summarized the activities planned to be made by the teachers in the next term as follows:

I gave the students some projects, but I want to give them as performance assignments and follow them up more strictly. I thought of increasing the experiments more. I want answers for questions such as. 'What wouldn't be in our daily life if physics didn't exist?' When I ask verbally, I don't get an answer; but I want to get their opinions in some subjects in writing. I need to think of creating more activities. Maybe this year was just an intensive semester; I was unprepared to apply the new program this year, but that was my fault (Teacher TF). 
The reason mentioned by most for not implementing certain activities this semester was a timebased problem. Apart from this, the teachers mentioned they lacked experience. Another notable result was that the teachers considered that the practices performed during the PD program will be internalized over time.

\section{How much of your expectations were met by this PD program?}

All of the teachers participating in the study mentioned that their expectations had mostly been met. They stated that they were pleased in having created a discussion environment in their PD sessions in which they shared their opinions and experiences (five teachers). They declared seeing themselves as stakeholders in the education process through a determination of needs prior to the PD program, and focusing of training in practice, as well as by given the opportunities for delivering lessons which significantly contributed towards their motivation. The following view of one teacher is given as example:

If we compare this course with courses from the Ministry of National Education, we would say that we only used to attend the course, listen to it, and come straight back. We undertook practical sessions in your course. We discussed the unit, we were taught, we made presentations and critiques, I mean, we didn't just come and sit, these were the best things. It was so different to the courses of the Ministry of National Education. We saw our errors and corrected them together (Teacher TA).

Suggestions put forward by teachers on the development of a PD program can be listed as follows:

- Worksheets and handouts could be prepared more;

- Workshop II could have been longer;

- It could have been connected with the other units;

- MoNE could support more (e.g., upgrade in position and salary); and,

- Other feedback mechanisms could be used in order to control regular on-the-job performance after the PD program (e.g., school community meetings, via online platforms, etc.).

5. Following the teachers' interviews, they were asked to assess the PD program using a fivepoint, Likert-type measurement that consisted of 12 questions

The participant teachers assessed the items between 4.6 and 5.0 points on average. The lowest score was given for the expression "I used the program materials in my lessons." One of the teachers who assessed the item with 3 points, said:

The student profile was inadequate. I saw that I couldn't obtain sufficient student feedback even though I tried to use it, which made me take a step backwards; I wanted to deliver the lesson in this way but nobody took notes, there were some students trying to make something, I mean, very few students completed their assignment (history of atom models), and there are some issues with the students' work, with some having just copied subjects from the Internet. It's not a problem though, but I think the more we reach, the better it will be, but thus far I couldn't create the requested student profile (Teacher TG).

The other eight items scored a full 5.0. The PD was found by the teachers to have been quite successful. In fact, longer PD programs with increased content levels were requested by some of the participating teachers. The overall scores for each item are given in Figure 3.

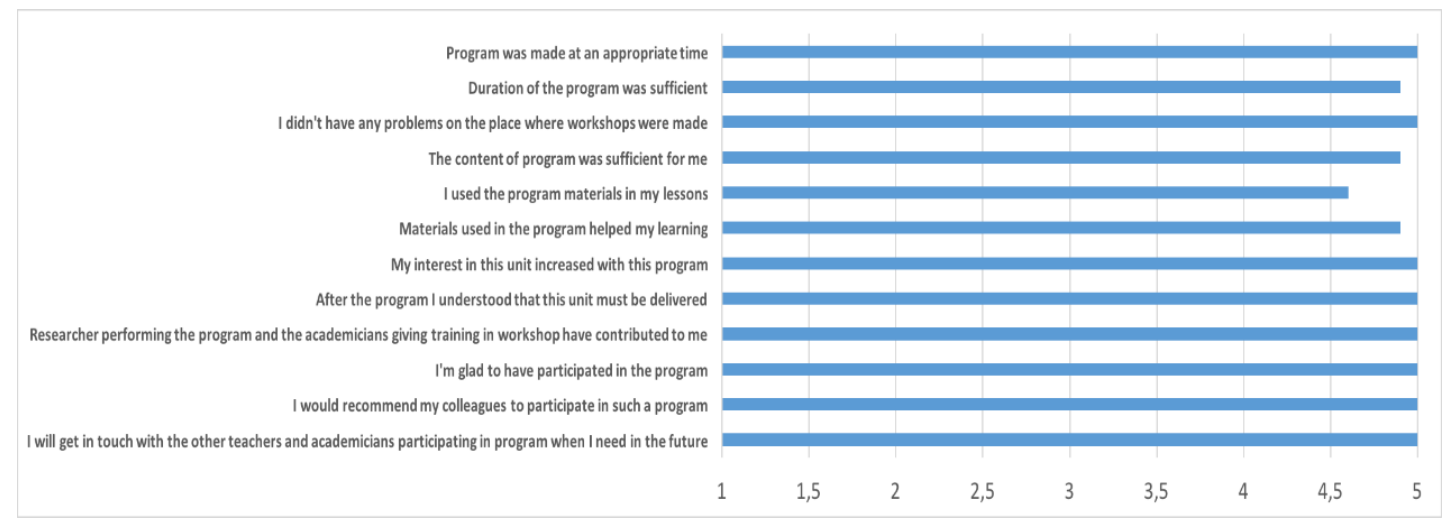

Figure 3. Assessment of PD program as a five-point, Likert-type measurement 


\title{
6. Do you have any additional suggestions or comments on the PD program? Please explain briefly.
}

As it was the first application this year, the teachers increased their awareness by clearly determining which unit content and skills objectives would be delivered and in what timeframe. Some of the teachers were unable to deliver their lessons in the way requested, but this may be due to the change not being immediately followed by practice as an internalization stage, as progress takes time.

Some of the teachers with good student success profiles mentioned that the general attitudes of the students towards physics impacted their practice.

\begin{abstract}
It is a really helpful experience when you talk to other teachers. We now communicate more with each other. All of us share ideas and I get to see how other colleagues practice in their schools, recommended certain practices to us, and provide constructive feedback in order to improve our own practices. I then come back to my school, and try to examine how it works for my students. I self-criticize my own practices more, and add or delete parts so as to improve my teaching (Teacher TD).
\end{abstract}

The teachers mentioned that they are used to making assessment by giving scores, but that they had not considered alternative assessment types for different purposes, as they saw in the workshop training. They reported on having wider availability of these kinds of assessments with having seen concrete examples from the PD program, and which thereby helped them to prepare similar assessment tools in their own classrooms.

All of the teachers indicated that observations of their lessons by the researcher proved to be very
useful. At first they said that they were a bit nervous and felt uncomfortable, but that they soon
became used to being observed by someone. One of the teachers stated that, "I had the chance to
see both my strengths and weaknesses during the teaching. You [the researcher] gave me feedback
and it makes me more concerned with and alert to both my lessons and my students" (Teacher TB).

Discussion, Conclusion and Recommendations

Teachers' evaluations were based on data captured using WSEC and PDEIP. According to the WSEC data, teachers were mostly satisfied with each of the PD program sessions, although they considered that the "Misconception" session made the least contribution when compared to the other sessions. Delivery of the unit was assessed by the PDEIP. Five teachers asserted that they used more student-centered methods which required student participation in the lesson. They indicated that they taught the unit with active student participation through the employment of different teaching strategies, visual materials, and assessment types, as well as the giving of assignments and projects in their classes following the PD program. Four of the teachers stated that they considered common topics and skills objectives during the teaching. Mostly, the teachers indicated using units, making hypotheses, mathematical modeling, and law, theory-related misconceptions as still seen as difficult subjects from the students' perspective. Both the teachers and the students have a weak understanding of the concepts related with NOS (Hipkins, Barker, \& Bolstad, 2005).

Based on their views, all of the teachers believed that they used more diverse (e.g., by making group works, doing different experiments) and better quality teaching strategies after the PD program. However, some students were not involved in these kinds of activities, therefore certain problems such as too much noise were reported to have occurred in group works. Five of the teachers mentioned that they used different materials (e.g., video, simulations, posters, history line, and board) following the PD program. In the same manner, they reported noise issues during the use of materials and technology in the classroom.

In terms of the assessment dimension, six of the teachers reportedly now consider objectives when preparing questions. They indicated they are now more familiar with summative assessment, as well as placement, diagnostic and formative assessment types. They were satisfied to see these types of assessments given with concrete examples. Two of the teachers explained the difficulty of making diagnostic and formative assessments because of time limitations. None of the teachers were familiar with placement assessment. After the PD program, three of the teachers started using placement purpose for the first time. Some of the teachers indicated that they could not use some of the activities due to time constraints. This could be seen as one of the barriers to the implementation of science contents following PD programs (Buczynski \& Hansen, 2010). Apart from this, the teachers considered that they 
would like to experience more similar types of training. One teacher (TG), from the lower group of teachers in terms of content, material/technology and assessment dimensions, emphasized that they learned most of the things during the PD program, but failed to apply them to the desired level. The teacher believed that such changes are not easy and that it requires time to practice more. PD attempts must not be seen as a one-shot process. Change needs time (Demirkol, 2010; Loucks-Horsley, Hewson, Love, \& Stiles, 1998).

All of the teachers expressed that they were satisfied with the development program. This result is similar to other studies on the effectiveness of PD programs (Finsterwald, Wagner, Schober, Lüftenegger, \& Spiel, 2013; Van Keer \& Verhaeghe, 2005). The teachers reported that the aspect of the PD program that they most liked were the discussions held in each session, where they could share their thoughts and opinions, take the opportunity for practice, and be an active being a member of the PD program in terms of the giving and receiving of guidance and feedback, and showing data as evidence about their teaching.

The teachers also assessed the PD program on a five-point, Likert-type scale. The range of the scores was 4.6 to 5.0 points on average. The lowest score was given to the item: "I used the products in training in my lessons." As a reason for this, one of the teachers (TG) remarked that she has very low level students. All of the teachers assessed that the PD program was quite successful for them. The results taken from the PD program evaluation interviews support the idea that teachers used more varied and richer teaching strategies in order to make their students more participative in their lessons. This study helps to see how those changes are meaningfully constructed in teachers' minds when participating in a PD program. It also shows which program elements (e.g., active participation, providing opportunity for practice, etc.) promote teachers' changes. It is hoped that these can be applied in the planning of future PD programs.

As a limitation, it is recognized that the study was conducted with only seven teachers, and that they are unlikely therefore to be representative for the majority of physics teachers. For a further study, the sample could be substantially increased and the research results generalized to other science teaching disciplines. In addition, different evaluation levels such as student outcomes could be used as evidence of measuring the impact of any proposed PD program.

\section{References}

Ball, D. L. (2000). Bridging practices: Intertwining content and pedagogy in teaching and learning to teach. Journal of Teacher Education, 51(3), 241-247.

Bell, B., \& Gilbert, J. (1996). Teacher development: A model from science education. London: Falmer.

Buczynski, S., \& Hansen, B. (2010). Impact of professional development on teacher practice: Uncovering connections. Teaching and Teacher Education 26(3), 599-607.

Cavallo, A. (2008). Experiencing the nature of science: An interactive, beginning-of-semester activity. Journal of College in Science Teaching, 37(5), 12-15.

Clossen, R. B. (2008). Use of problem-based learning and case study in continuing professional education. Journal of Continuing Higher Education, 56(2), 34-44.

Demirkol, M. (2010). İlköğretim okullarında öğretmenlere yönelik okul-temelli hizmet içi eğitim etkinliklerinin değerlendirilmesi [The evaluation of school-based in-service training in elementary education]. The Journal of National Education, 40(188), 158-173.

Finsterwald, M., Wagner, P., Schober, B., Lüftenegger, M., \& Spiel, C. (2013). Fostering lifelong learning evaluation of a teacher education program for professional teachers. Teaching and Teacher Education, 29, 144-155.

Guskey, T. R. (1986). Staff development and the process of teacher change. Educational Researcher, 15(5), 5-12.

Guskey, T. R. (2000). Evaluating professional development. Thousand Oaks, CA: Sage Publications. 
Guskey, T. R., \& Sparks, D. (1996). Exploring the relationship between staff development and improvements in student learning. Journal of Staff Development, 17(4), 34-38.

Hipkins, R., Barker, M., \& Bolstad, R. (2005). Teaching the "nature of science": Modest adaptations or radical reconceptions? International Journal of Science Education, 27(2), 243-254.

Kubitskey, B., Fishman, B., \& Marx, R. (2002). The relationship between professional development and student learning: Exploring the link through design research. Annual Meeting of the American Educational Research Association. Chicago, IL.

Loucks-Horsley, S., Hewson, P. W., Love, N., \& Stiles, K. E. (1998). Designing Professional development for teachers of science and mathematics. Thousand Oaks, CA: Corwin Press.

Miles, M. B., \& Huberman, A. M. (1994). Qualitative data analysis (2nd ed.). Thousand Oaks, CA: Sage.

Oktay, Ö. (2015). The effects of a professional development program on physics teachers' classroom practices. Unpublished Doctoral dissertation, Middle East Technical University, Ankara.

Ornstein, A. C., \& Hunkins, F. P. (1988). Curriculum: Foundations, principles and issues. Englewood Cliffs, NJ: Prentice-Hall.

Van Keer, H., \& Verhaeghe, J. P. (2005). Comparing the teacher development programs for innovating reading comprehension instruction with regard to teachers' experience and student outcomes. Teaching and Teacher Education, 21(5), 543-562. 